\title{
The Influence of Brand Image, Halal Label, and Product Quality on Kentucky Fried Chicken (KFC) Purchase Decisions
}

\author{
Pini Apriliani ${ }^{1 *}$, Tikawati Tikawati ${ }^{1}$, and Nurul Fadhilah ${ }^{1}$ \\ ${ }^{1}$ Faculty Economic and Islamic Bussiness, Sultan Aji Muhammad Idris Islamic University, \\ Samarinda, Indonesia
}

\begin{abstract}
This study aims to determine the effect of brand image, halal label, and product quality either simultaneously or partially on the purchasing decision of KFC in Samarinda. In this study, researchers used quantitative research. Data collection techniques with questionnaires, interviews, and literature study. Determination of the number of samples based on the slovin formula amounted to 100 respondents. The analytical technique used in this research is instrument test, classical assumption test, multiple regression analysis, and hypothesis testing using SPSS version 22. The study results prove that brand image partially has a significant effect on purchasing decisions for KFC in Samarinda, Halal label partially has a significant effect on purchasing decisions for KFC at Samarinda, Product quality partially has a significant effect on purchasing decisions for KFC at Samarinda. Brand Image, Halal Label, and Product Quality simultaneously significantly influenced purchasing decisions for KFC at Samarinda. The results of this study are expected to be an evaluation for culinary business developers to understand better the characteristics of their consumers and what they need and want. Thus the company will more easily attract the interest of consumers.
\end{abstract}

\section{Introduction}

The increasing mobility of people and busy work activities have resulted in them always looking for something practical and instant in fulfilling their daily needs. One of them is by looking for food and drinks outside the home to meet their needs. It can be said that the habit of eating in fast-food restaurants has become an inseparable part of people's lives today (Silaban et al., 2019). The public's high interest to eat out of the home, of course, creates intense competition in this business world. So now, business actors must be able to understand customer needs. The need for food and drink is a basic human need that must be fulfilled so that the fast-food business becomes a trend among the Indonesian people; one of the fast-foods currently developing is fried chicken (Hidayah et al., 2019).

\footnotetext{
*Corresponding author: piniapriliani09@gmail.com
} 


\section{$A \mathrm{C} \overline{I E B}$ Annual International Conference \\ on Islamic Economics and Business, 2021}

According to data from the Ministry of Agriculture in 2019. Indonesia produced 2,334,042 tons of broiler meat production (Ministry of Agriculture of the Republic of Indonesia, 2019). Most broiler meat production is processed in fried chicken such as C'Best, California Fried Chicken (CFC), Texas Chicken, McDonald's, Hoka-Hoka Bento, Kentucky Fried Chicken (KFC), Richeese Factory, and Fried Chicken which still have local potential. This makes KFC continuously strengthen its image to achieve the highest position in the hearts of consumers. Various strategies have been carried out by KFC such as continuously creating innovative strategies and ideas, maintaining product quality and deliciousness, and KFC has obtained a halal certificate (Firmanto, 2019). In addition, the atmosphere can be enhanced by designing a unique theme and keeping repeat customers in a positive environment, creating a place for young people to take pictures following trends on social networks (Nguyen, 2021). Companies implement strategies to create a favourable image in consumer's minds (Soomro et al., 2021).

KFC itself is the first fast food in Indonesia which was founded by Gelael Group in 1978 as the first party to obtain a KFC franchise for Indonesia. With time the company is growing very fast and achieving success. The success of this first KFC outlet was followed by the opening of other outlets in Jakarta to experience an area expansion throughout the city, one of which was KFC in Samarinda, which was first established on December 9 1995. This KFC restaurant has its icon, namely "Jagonya Ayam", because the main menu offered by KFC is tender and crispy fried chicken.

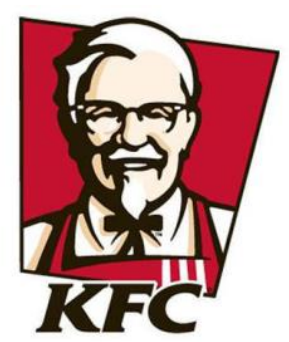

Fig. 1. Logo KFC

KFC is one of the fast-food restaurants that have a strong brand image. A strong brand image can help balance consumer perceptions (Bhakuni et al., 2021). This is evidenced by KFC being ranked first on Top Brand in 2019, 2020, 2021(Top Brand Award, 2021). And many other awards, such as Indonesia Millennials Top Brand Award 2019, Top Digital Public Relations Award 2020, and Digital Popular Brand Award 2021 for the Fried Chicken restaurant category by TRAS N CO Indonesia and InfoBrand.Id. With the awards that have been obtained, does this affect consumers in making KFC decisions in Samarinda, because before a consumer chooses and then decides to purchase a particular product, the consumer will go through several processes before making a decision. And in making purchasing decisions, one of them is influenced by brand image (Brand Image) (Setyawati, 2018).

In addition, the process of selecting halal products or halal labels on products will be one of the consumer factors in purchasing decisions (Hernama et al., 2021). Indonesia is a country with a majority Muslim population, it should be able to maintain religious values, including in terms of consuming food and beverages (Dewanti et al., 2021). Consuming halal products, especially halal food is a condition stipulated in Islamic law as confirmed in the word of Allah SWT in the Qur'an:

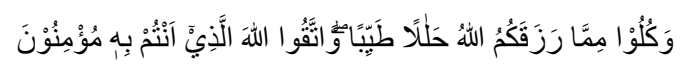




\section{$A I C \overline{I E B}$ Annual International Conference \\ on Islamic Economics and Business, 2021}

Translation: "Eat what Allah has given you as a lawful and good sustenance, and fear Allah in whom you believe" (Al-Maidah: 88).

On that basis, Muslims in line with Islamic teachings want the products to be consumed to be guaranteed halal and pure. Products that do not include a halal label on their packaging are considered not to have received approval from the competent authority (LPPOM-MUI) to be classified into the list of halal products or are considered to be still in doubt about their halalness and KFC cares about that. KFC is also one of the restaurants that have received the MUI halal certificate since 1995, and always renews the MUI halal certificate before it expires.

Not just halal labels, consumer purchasing decisions can be influenced by several things, including decisions about prices, product types, product design, and product quality (Agatha, 2018). Product quality is an important thing that must be strived by every company if you want the products sold to compete in the market (Dewanti et al., 2021). Product quality is a characteristic of a product that is implied to be able to satisfy consumer needs (Asti et al., 2020). Consumers will assess of the food products offered based on the quality of taste, aroma, elasticity, and compliance with health standards. The tendency of consumers to choose products based on quality standards. The importance of production process control can produce quality products (Hoe et al., 2018).

Based on previous researchers, Rina Rachel Pilipus et.al., stated that Word of Mouth and brand image do not affect on purchasing decisions, while product quality had an effect and can be replaced with an alternative method of E-WOM (Electronic Word Of Mouth) which in delivering information now in the digital and modern era is more focused on using social media such as Instagram, Facebook, and other social media. Thus, the use of the E-WOM alternative makes it easier to convey information on Dum Dum Thai Drinks products so that they can be more easily recognized and remembered and become the consumer's main choice in purchasing decisions for Dum Dum Thai Drinks Drinks Samarinda (Pilipus et al., 2021).

However, there is a research gap which is the result of previous studies that have been carried out. The results of different studies indicate that there is a research gap on the influence of brand image, halal label and product quality on purchasing decisions. The results of the study can be seen in Table 1 below.

Table 1. research gap which is the result of previous studies that have been carried out.

\begin{tabular}{|l|c|c|}
\hline \multicolumn{1}{|c|}{ Variable relationship } & Have influence & Have no influence \\
\hline $\begin{array}{l}\text { The influence of brand } \\
\text { image on purchasing } \\
\text { decisions }\end{array}$ & $\begin{array}{l}\text { 1. Rizka Nur Fauziah } \\
(2019)\end{array}$ & $\begin{array}{l}\text { 1. Rina Rachel Pilipus } \\
\text { et.al., (2021) }\end{array}$ \\
\hline $\begin{array}{l}\text { Effect of halal label on } \\
\text { purchasing decisions }\end{array}$ & $\begin{array}{l}\text { 1. Hardiansyah et al., } \\
\text { Manurung (2020) }\end{array}$ & $\begin{array}{l}\text { 1. Dendy Khresna Bayu } \\
\text { et al., (2020) }\end{array}$ \\
\hline $\begin{array}{l}\text { The influence of product } \\
\text { quality on purchasing } \\
\text { decisions }\end{array}$ & $\begin{array}{l}\text { 1. Hardiansyah, Heri } \\
\text { Prasuhanda Manurung } \\
(2020)\end{array}$ & $\begin{array}{l}\text { 1. Rizka Nur Fauziah } \\
\text { (2019) }\end{array}$ \\
\hline
\end{tabular}

Rizka Nur Fauziah stated that partially the quality of the product has no effect on purchasing decisions, Brand Image has an effect on purchasing decisions. Simultaneously, Brand Image and product quality have a significant effect on purchasing decisions. So when viewed from an economic point of view, the possible cause of product quality does not partially affect purchasing decisions because consumers only see the brand image of famous artists, not from the quality of the products offered. Consumers do not pay too much attention to the quality of their products but look at the brand image of the company so that consumers feel proud because they have consumed the products of one of these famous artists (Fauziah, 2019). 


\section{$A \mathrm{C} \overline{I E B}$ Annual International Conference \\ on Islamic Economics and Business, 2021}

Dendy Khresna Bayu et al., stated that Halal labels have no effect on purchasing decisions. Halal labeling, brand, and price simultaneously affect purchasing decisions. This shows that people will continue to buy products even without the halal label. This is certainly not by the command of Allah in Surah Al-Baqarah verse 168 which means "O people, eat what is lawful and good..." (Bayu et al., 2020).

Hardiansyah et al., the results of the study show that the halal label, product quality, and price partially and simultaneously affect the Purchase Decision for White Koffie Luwak Products. In making purchasing decisions for white koffie civet products, the public always pays attention to the halal label, product quality and prices offered according to the ability of consumers (Hardiansyah, 2020).

Based on the background, researchers are interested in knowing whether brand image, halal label and product quality affect the purchasing decision of KFC in Samarinda. This research can be used as study material and consideration for both business entities and educational institutions regarding purchasing decisions, which in this study are associated with brand image, halal label and product quality. The results of this study are closely related to purchasing decisions which are very much needed in developing businesses, especially in Muslim-majority countries. More than that, this research is also a reference in formulating purchasing decision system policies for students, especially Islamic economics study programs which can later be applied to every business entity, especially in the halal industry.

\section{Literature Review}

\subsection{Brand Image}

Brands are the initial The brand is the starting point of an introduction between consumers and producers (Susanti et al., 2015). According to Kotler \& Keller, image is a belief, idea and impression held by a person about an object (Kotler et al., 2009). Brand image is the public's perception of the company or its products. Thus, brand image or brand image is a representation of the overall perception of the brand and is formed from information and past experiences of the brand. And empirical studies have revealed that brand image boosts consumer confidence (Zeng., 2019).

\subsection{Halal Label}

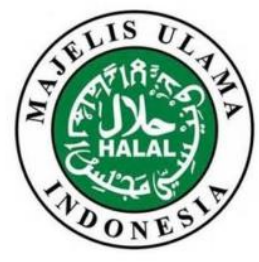

Fig. 2. Logo Halal

Halal labels are halal writings or statements on product packaging to indicate that the product in question is a halal product (Mashudi, 2015). Considering that Muslims are one of the largest markets in the world, halal products are a determining factor in product strategy in their marketing mix, so that the Muslim market becomes more interested in halal products (Bulan et al., 2018). 


\section{$\triangle \mathrm{C} \overline{I E B}$ Annual International Conference \\ on Islamic Economics and Business, 2021}

\subsection{Product Quality}

According to According to Kotler and Armstrong, product quality is the ability of a product to perform its functions which include durability, reliability, accuracy, convenience, operation, and repair as well as other attributes (Kotler et al., 2008). For a company, the product has a very important role because the company is not able to run its business without a product and product performance is directly affected by product quality (Sari, 2021). And quality will be used as the dominant input to make purchasing decisions ( $\mathrm{Li}$ et al., 2021). Thus, product quality is a priority in business (Zhu et al., 2020).

\subsection{Purchasing Decision}

Purchasing decision is one of the stages in the buying decision process before post-purchase behavior. Basically, consumers always try to fulfill their needs and wants (Alshare et al., 2020). In entering the previous purchase decision stage, consumers have been faced with several alternative choices so that at this stage consumers will take action to decide to buy products based on the choices specified (Marisa et al., 2019). According to Philip Kotler and Kevin Keller, consumers go through five stages of the decision-making process, namely: problem recognition, information search, alternative evaluation, purchase decisions, and post-purchase behavior (Kotler et al., 2009). Consumers are often met with many options for using a product or service. The number of consumers in making decisions is one of the determinants of whether the company can achieve its goals (Azam, 2019).

\section{Methodology Research}

The type of research used in this study is a type of quantitative research. The population in this study are consumers of KFC in Samarinda, totaling 14.000 people every month. The sampling technique in this study used the basis for sampling from the slovin formula, namely:

$$
\begin{gathered}
\mathrm{n}=\frac{N}{1+N \cdot e^{2}} \\
\mathrm{n}=\frac{14.000}{1+\left(14.000 \times 0,1^{2}\right)} \\
\mathrm{n}=\frac{14.000}{1+(14.000 \times 0,01)} \\
\mathrm{n}=99,29 \text { rounded up to } 100 \text { respondents. }
\end{gathered}
$$

Sources of data used at the time of the study were primary data and secondary data. Primary data is also called original data or new data (Hasan, 2003). In this study, the primary data used were consumers of Kentucky Fried Chicken (KFC) in Samarinda as respondents, through questions distributed in the form of questionnaires or questionnaires. Secondary data is data that has been collected by other parties. Secondary data comes from reading materials such as books, journals, research results, newspapers, and others that can support primary 


\section{$\mathrm{AIC} \overline{\mathrm{IEB}} \quad \begin{aligned} & \text { Annual International Conference } \\ & \text { on Islamic Economics and Business, } 2021\end{aligned}$}

data (Kountor, 2005). The analysis techniques used in this study are validity test, reliability test, normality test, test multicollinearity, heteroscedasticity test, multiple linear regression analysis, Coefficient of Determination $\left(R^{2}\right), \mathrm{t}$ test, $\mathrm{F}$ test.

\section{Result and Discussion}

\subsection{Research Instrument Test Results}

\subsubsection{Validity Test}

Table 2. Brand Image Variable Instrument Validity Test (X1)

\begin{tabular}{|c|c|c|c|}
\hline Items Question & r-count & r-table & Description \\
\hline Statement 1 & 0.680 & 0.195 & Valid \\
\hline Statement 2 & 0.664 & 0.195 & Valid \\
\hline Statement 3 & 0.631 & 0.195 & Valid \\
\hline Statement 4 & 0.483 & 0.195 & Valid \\
\hline Statement 5 & 0.658 & 0.195 & Valid \\
\hline Statement 6 & 0.745 & 0.195 & Valid \\
\hline Statement 7 & 0.738 & 0.195 & Valid \\
\hline
\end{tabular}

Table 3. Halal Label Variable Instrument Validity Test (X2)

\begin{tabular}{|c|c|c|c|}
\hline Question Items & r-count & r-table & Information \\
\hline Statement 1 & 0.849 & 0.195 & Valid \\
\hline Statement 2 & 0.862 & 0.195 & Valid \\
\hline Statement 3 & 0.908 & 0.195 & Valid \\
\hline Statement 4 & 0.802 & 0.195 & Valid \\
\hline
\end{tabular}

Table 4. Product Quality Variable Instrument Validity Test (X3)

\begin{tabular}{|c|c|c|c|}
\hline Question Items & r-count & r-table & Information \\
\hline Statement 1 & 0.737 & 0.195 & Valid \\
\hline Statement 2 & 0.686 & 0.195 & Valid \\
\hline Statement 3 & 0.781 & 0.195 & Valid \\
\hline Statement 4 & 0.728 & 0.195 & Valid \\
\hline Statement 5 & 0.618 & 0.195 & Valid \\
\hline Statement 6 & 0.777 & 0.195 & Valid \\
\hline Statement 7 & 0.706 & 0.195 & Valid \\
\hline Statement 8 & 0.694 & 0.195 & Valid \\
\hline
\end{tabular}

Table 5. Test the Validity of the Purchase Decision Variable Instrument (Y)

\begin{tabular}{|c|c|c|c|}
\hline Question Items & r-count & r-table & Information \\
\hline Statement 1 & 0.655 & 0.195 & Valid \\
\hline Statement 2 & 0.530 & 0.195 & Valid \\
\hline Statement 3 & 0.680 & 0.195 & Valid \\
\hline Statement 4 & 0.473 & 0.195 & Valid \\
\hline Statement 5 & 0.572 & 0.195 & Valid \\
\hline Statement 6 & 0.608 & 0.195 & Valid \\
\hline Statement 7 & 0.531 & 0.195 & Valid \\
\hline Statement 8 & 0.680 & 0.195 & Valid \\
\hline
\end{tabular}




\section{$A I \overline{I F B}$ Annual International Conference \\ on Islamic Economics and Business, 2021}

Each item of a valid questionnaire statement can be used as a reference for further research. In this questionnaire, all items in the instrument brand image (X1), halal label (X2), product quality (X3) and purchasing decisions (Y) have met the requirements of validity or validity through statistical data processing.

\subsubsection{Reliability Test}

Table 6. Reliability Test Results

\begin{tabular}{|l|c|c|}
\hline \multicolumn{1}{|c|}{ Variable } & Crobanch's Alpha & Information \\
\hline Brand Image (X1) & 0.774 & Reliable \\
\hline Halal Label (X2) & 0.875 & Reliable \\
\hline Product Quality (X3) & 0.862 & Reliable \\
\hline Purchase Decision (Y) & 0.734 & Reliable \\
\hline
\end{tabular}

Based on table, it can be seen that the value of Cronbach's Alpha is greater than 0.60, namely the brand image variable value of 0.774 , halal label is 0.875 , product quality is 0.862 , purchase decision is 0.734 , so it can be said to be reliable which means that the questionnaire used in this study is a good questionnaire.

\subsection{Classic Assumption Test Results}

\subsubsection{Normality test}

Table 7. Reliability Test Results

\begin{tabular}{|c|c|}
\hline & Unstandardized Residual \\
\hline $\begin{array}{cc}\mathrm{N} & \\
\text { Normal Parameters, b } & \text { mean } \\
\text { Most Extreme Differences } & \text { Std. Deviation } \\
& \begin{array}{c}\text { Absolute } \\
\text { Positive } \\
\\
\text { Test Statistics } \\
\text { negative }\end{array} \\
\text { asymp. Sig. (2-tailed) } & \end{array}$ & $\begin{array}{c}100 \\
.0000000 \\
2.07558027 \\
.056 \\
.056 \\
-.053 \\
.056 \\
.200 \mathrm{c}, \mathrm{d}\end{array}$ \\
\hline
\end{tabular}

a. Test distribution is Normal.

b. Calculated from data.

Based on the results shown in the table, the significance of the normality test is 0.200 where the value is greater than 0.05 . So it can be concluded that the assumption of normality is met.

\subsubsection{Multicollinearity Test}

The multicollinearity test aims to detect the presence or absence of multicollinearity in the regression model. 


\section{$A I \overline{I E B}$ Annual International Conference \\ on Islamic Economics and Business, 2021}

Table 8. Multicollinearity Test Results

Coefficientsa

\begin{tabular}{|c|c|c|c|c|c|c|c|c|}
\hline & \multirow[b]{2}{*}{ Model } & \multicolumn{2}{|c|}{$\begin{array}{l}\text { Unstandardized } \\
\text { Coefficients }\end{array}$} & \multirow{2}{*}{\begin{tabular}{|c}
$\begin{array}{c}\text { Standardized } \\
\text { Coefficients }\end{array}$ \\
Beta \\
\end{tabular}} & \multirow[b]{2}{*}{$\mathrm{t}$} & \multirow[b]{2}{*}{ Sig. } & \multicolumn{2}{|c|}{$\begin{array}{l}\text { Collinearity } \\
\text { Statistics }\end{array}$} \\
\hline & & B & Std. Error & & & & $\begin{array}{c}\text { Toleranc } \\
\mathrm{e}\end{array}$ & VIF \\
\hline \multirow[t]{4}{*}{1} & (Constant) & 7,248 & 2.257 & & 3.211 & .002 & & \\
\hline & Brand Image & .189 & .090 & .182 & 2,092 & .039 & .573 & 1,746 \\
\hline & Halal Label & .385 & .111 & .285 & 3.450 & .001 & .635 & 1.574 \\
\hline & $\begin{array}{l}\text { Product } \\
\text { quality }\end{array}$ & .392 & .071 & .448 & 5.555 & .000 & .667 & 1.498 \\
\hline
\end{tabular}

a. Dependent Variable: Purchase Decision

Based on table XIII, it is known that the Tolerance value is greater than 0.10 . This can be seen from the brand image value of 0.573 , halal label of 0.635 and product quality of 0.667 . The VIF value in the table shows that it is smaller than 10 , this can be seen from the brand image value of 1.746 , halal label of 1.574 , product quality of 0.667 . Thus, it can be concluded that the regression model under study does not have multicollinearity symptoms.

\subsubsection{Heteroscedasticity Test}

This test aims to see whether there is an inequality of variance in the residuals from one observation to another. In this study using the glejser test, where if the significance value between the independent variable and the absolute residual is greater than 0.05 , there is no heteroscedasticity problem.

Table 9. Heteroscedasticity Test Results

\begin{tabular}{|c|c|c|c|c|c|c|}
\hline \multicolumn{7}{|c|}{ Coefficientsa } \\
\hline & \multirow[b]{2}{*}{ Model } & \multicolumn{2}{|c|}{ Unstandardized Coefficients } & \multirow{2}{*}{$\begin{array}{l}\text { Standardized } \\
\text { Coefficients } \\
\text { Beta }\end{array}$} & \multirow[b]{2}{*}{$\mathrm{t}$} & \multirow[b]{2}{*}{ Sig. } \\
\hline & & B & Std. Error & & & \\
\hline \multirow[t]{4}{*}{1} & (Constant) & 1,626 & 1.397 & & 1.164 & .247 \\
\hline & Brand Image & -.008 & .056 & -.019 & -.139 & .890 \\
\hline & Halal Label & -.051 & .069 & -.095 & -.743 & .459 \\
\hline & Product quality & .034 & .044 & .096 & .774 & .441 \\
\hline
\end{tabular}

a. Dependent Variable: Abs_Res

Based on the results shown in the table above, each variable has a significance value greater than 0.05 , where the significance value of brand image is 0.890 , halal label is 0.459 , and product quality is 0.441 . So it can be concluded that there is no heteroscedasticity problem. 


\section{$A I \overline{I F B}$ Annual International Conference \\ on Islamic Economics and Business, 2021}

\subsection{Multiple Linear Regression Analysis Results}

This researcher uses multiple regression analysis method. From data processing, the following results were obtained:

Table 10. Multiple Linear Regression Analysis Results

Coefficientsa

\begin{tabular}{|c|c|c|c|c|c|c|}
\hline & \multirow[b]{2}{*}{ Model } & \multicolumn{2}{|c|}{ Unstandardized Coefficients } & \multirow{2}{*}{$\begin{array}{c}\text { Standardized } \\
\text { Coefficients } \\
\text { Beta } \\
\end{array}$} & \multirow[b]{2}{*}{$\mathrm{t}$} & \multirow[b]{2}{*}{ Sig. } \\
\hline & & $\mathrm{B}$ & Std. Error & & & \\
\hline \multirow[t]{4}{*}{$\overline{1}$} & (Constant) & 7,248 & 2.257 & & 3.211 & .002 \\
\hline & Brand Image & .189 & .090 & .182 & 2,092 & .039 \\
\hline & Halal Label & .385 & .111 & .285 & 3.450 & .001 \\
\hline & Product quality & .392 & .071 & .448 & 5.555 & .000 \\
\hline
\end{tabular}

a. Dependent Variable: Purchase Decision

Based on the results of multiple regression above, the regression statement is obtained, namely:

$\mathrm{Y}=7.248+0.189 \times 1+0.385 \times 2+0.392 \times 3$

Information:

$\mathrm{Y}=$ Purchase Decision

$\mathrm{X} 1$ = Brand Image

$\mathrm{X} 2=$ Halal Label

$\mathrm{X} 3$ = Product Quality

From the regression equation above, it can be interpreted as follows:

1. The constant value (a) obtained is 7.248 , indicating that when the independent variables (brand image, halal label, and product quality) are constant, the level of purchasing decisions is 7.248.

2. The regression coefficient $\mathrm{X} 1=0.189$ states that the brand image variable is positive for purchasing decisions. This shows that if the brand image has increased by 1 unit, then the purchase decision will increase by 0.189

3. The regression coefficient $\mathrm{X} 2=0.385$ states that the halal label variable is positive for purchasing decisions. This shows that if the halal label has increased by 1 unit, then the purchase decision will increase by 0.385 .

4. The regression coefficient $\mathrm{X} 3=0.392$ states that the product quality variable has a positive sign on purchasing decisions. This shows that if the quality of the product increases by 1 unit, then the purchase decision will increase by 0.392 .

\subsection{Hypothesis Test Results}

\subsubsection{Coefficient of Determination Test Results $\left(R^{2}\right)$}

The coefficient of determination is used to determine how much influence the variable $\mathrm{X}$ has on Y. The results of the coefficient of determination test can be seen in the following table: 


\section{$A I C \overline{I E B}$ Annual International Conference \\ on Islamic Economics and Business, 2021}

Table 11. Coefficient of Determination Test Results Model Summary

\begin{tabular}{|c|c|c|c|c|}
\hline Model & $\mathrm{R}$ & R Square & Adjusted R Square & $\begin{array}{c}\text { Std. Error of the } \\
\text { Estimate }\end{array}$ \\
\hline 1 & $.764 \mathrm{a}$ & .583 & .570 & 2.10776 \\
\hline
\end{tabular}

a. Predictors: (Constant), Product Quality, Halal Label, Brand Image

Based on the table above, it can be seen that the coefficient of determination is 0.570 or $57 \%$. This shows that the influence of brand image, halal label and product quality on purchasing decisions is $57 \%$, while the remaining $43 \%$ is influenced by other variables not included in this research model.

\subsection{2 $\mathrm{T}$ test results}

The $t$ test is used to test the effect of each independent variable on the dependent variable, namely to test whether brand image (X1), halal label (X2), product quality (X3) partially have a significant effect on purchasing decisions (Y).

The decision-making criteria in the test are divided into two ways, namely:

a. Pay attention to the value of sig. $<0.05$

b. Pay attention to value $t_{\text {hitung }}$ and $t_{\text {tabel }}$. If $t_{\text {count }}>t_{\text {table }}$ then $\mathrm{H} 0$ is rejected and Ha is accepted, which means that the independent variable partially affects the dependent variable.

$$
\begin{aligned}
t_{\text {tblel }} & =(\alpha / 2 ; \mathrm{nk}-1) \\
& =(0.05 / 2 ; 100-3-1) \\
& =0.025 ; 96
\end{aligned}
$$

So, value $t_{\text {table }}$ what is obtained is 1.988 .

Information:

$\boldsymbol{\alpha}=$ Confidence level (0.05)

$\mathrm{n}=$ Number of samples

$\mathrm{k}=$ Number of variables

\begin{tabular}{|c|c|c|c|c|c|c|}
\hline \multirow{2}{*}{\multicolumn{2}{|c|}{ Model }} & \multicolumn{2}{|c|}{ Unstandardized Coefficients } & \multirow{2}{*}{$\begin{array}{c}\begin{array}{c}\text { Standardized } \\
\text { Coefficients }\end{array} \\
\text { Beta }\end{array}$} & \multirow[b]{2}{*}{$\mathrm{t}$} & \multirow[b]{2}{*}{ Sig. } \\
\hline & & $\mathrm{B}$ & Std. Error & & & \\
\hline 1 & (Constant) & 7,248 & 2.257 & & 3.211 & .002 \\
\hline & Brand Image & .189 & .090 & .182 & 2,092 & .039 \\
\hline & Halal Label & .385 & .111 & 285 & 3.450 & .001 \\
\hline & Product quality & .392 & .071 & .448 & 5.555 & .000 \\
\hline
\end{tabular}

The results of the t-test data processing can be seen in the table below.

Table 11. T Test Result Coefficientsa

a. Dependent Variable: Purchase Decision 


\section{$A I C \overline{I E B}$ Annual International Conference \\ on Islamic Economics and Business, 2021}

Based on the results of Table XVII, namely:

a. Brand image (X1) on Purchase Decision (Y)

Brand image has a significant value of $0.039<0.05$ and $t_{\text {count }}>t_{\text {table }}$ of $2.092>1.988$ then $\mathrm{H}_{01}$ is rejected and $\mathrm{H}_{a 1}$ is accepted. This means that brand image partially has a significant effect on purchasing decisions for KFC in Samarinda..

b. Halal Label (X2) on Purchase Decision (Y)

Halal label has a significant value of $0.001<0.05$ and $t_{\text {count }}>t_{\text {table }}$ of $3.450>1.988$ then $\mathrm{H}_{02}$ is rejected and $\mathrm{H}_{a 2}$ is accepted. This means that the halal label partially has a significant effect on the purchasing decision of KFC in Samarinda.

c. Product quality (X3) on Purchase Decision (Y)

The product quality has a significant value of $0.000<0.05$ and $t_{\text {count }}>t_{\text {table }}$ of $5.555>$ 1.988 then $\mathrm{H}_{03}$ is rejected and $\mathrm{H}_{a 3}$ is accepted. This means that product quality partially has a significant effect on purchasing decisions for KFC in Samarinda.

\subsubsection{F Test Results}

The $\mathrm{F}$ test is used to test the independent variable (X) simultaneously or together which has a significant or insignificant effect on the dependent variable $(\mathrm{Y})$. if the value of sig. less than 0.05 and the value of $F_{\text {count }}>F_{\text {table }}$, then $\mathrm{H}_{04}$ is rejected and $\mathrm{H}_{a 4}$ is accepted.

$$
\begin{aligned}
F_{\text {table }} & =\mathrm{k} ; \mathrm{n}-\mathrm{k} \\
& =3 ; 100-3 \\
& =3 ; 97 \\
& =2.70
\end{aligned}
$$

Table 12. F Test Result.

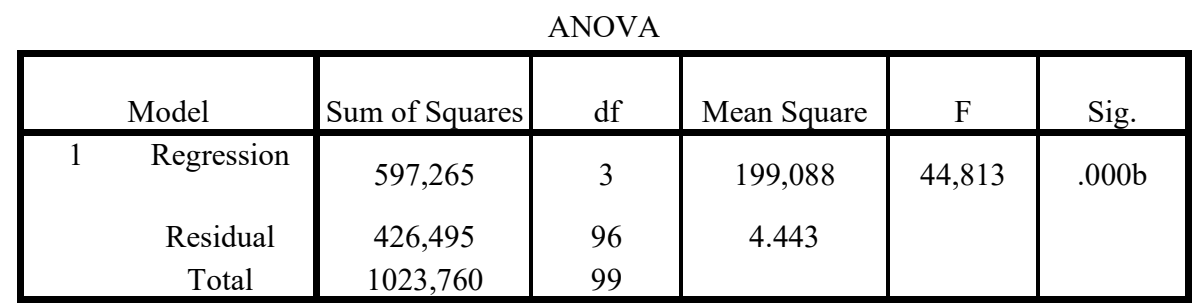

a. Dependent Variable: Purchase Decision

b. Predictors: (Constant), Product Quality, Halal Label, Brand Image

Based on the results of the $\mathrm{f}$ test in the table above, it can be seen that the significant value is $0.000<0.05$ and the value of $F_{\text {count }}$ is 44.813 so that $F_{\text {count }}>F_{\text {table }}(44.813>2.70)$. It can be concluded that $\mathrm{H}_{04}$ is rejected and $\mathrm{H}_{a 4}$ is accepted, which means that the variable brand image (X1), halal label (X2), product quality (X3) simultaneously have a significant effect on purchasing decisions (Y).

\subsection{Discussion}

\subsubsection{Effect of Brand Image (X1) on Purchase Decision (Y)}

Based on the results of the test, $\mathrm{H}_{01}$ is rejected and $\mathrm{H}_{a 1} 1$ is accepted. Hypothesis $\mathrm{X}_{1}$ is obtained that brand image has a significant positive effect on purchasing decisions of KFC in Samarinda. Testing the influence of the brand image variable on the purchasing decision 


\section{$A T \overline{C E B}$ Annual International Conference \\ on Islamic Economics and Business, 2021}

of KFC in Samarinda is known with a significant value of $0.039<0.05$ which indicates the influence of the brand image variable on the purchasing decision of KFC in Samarinda. Another way to prove that brand image has a significant influence on purchasing decisions for KFC in Samarinda is to compare $t_{\text {count }}$ and $t_{\text {table }}$. From this comparison, it is found that $t_{\text {count }}>t_{\text {table }}$ is $2,092>1,988$, it is concluded that accepting $\mathrm{H}_{a 1}$ which means that brand image has a significant influence on purchasing decisions of KFC in Samarinda.

This is reinforced by the theory that brand image has an important role in influencing consumer decision making to choose a product (Alić et al., 2020), because when consumers have a good/positive image of a brand, consumers will tend to choose to buy the product (Fitria et al., 2017). This opinion is also reinforced by Richardson et al in the journal Popy and Sumiyarsih who state that brand image is often used as a condition for making a purchase decision (Andrew, 2021). Building a strong brand image in the minds of customers or consumers is a long-term investment for the company, because the brand is a prestigious asset for the company and can bring the company to the peak of its success (Prastya, 2020). Each company also has specific strategies implemented to attract customers to buy its products, as did KFC in Samarinda. With the capital of the big name KFC which has become one of the popular brands in the world, KFC in Samarinda continues to try to maintain its brand image in various ways, such as guaranteeing the quality of the products produced, maintaining the trust that has been given by consumers, friendly service and speed of checkout. in serving consumers, and a pleasant restaurant atmosphere with a modern design. These strategies have proven to be able to make the image of KFC in Samarinda positively accepted by consumers, which in turn can become a reference for consumers.

The results of this study are in line with research conducted by Rizka Nur Fauziah,However, this research contradicts the research conducted Rina Rachel Pilipus, M. Fikry Aransyah, and Wira Bharata. From the calculation of SPSS Statistics, it is shown that the brand image variable has no partial effect. Evidenced by significant results showing the number 0,15 which is greater than 0.05 .

\subsubsection{Effect of Halal Label (X2) on Purchase Decision (Y)}

Based on the results of the t test $\mathrm{H}_{02}$ is rejected and $\mathrm{H}_{\mathrm{a} 2}$ is accepted. Hypothesis $\mathrm{X}_{2}$ is obtained that the halal label has a significant positive effect on the purchasing decision of KFC in Samarinda. Testing the effect of the halal label variable on the purchasing decision of KFC in Samarinda is known with a significant value of $0.001<0.05$ which indicates the influence of the halal label variable on the purchasing decision of KFC in Samarinda. Another way to prove that the halal label has a significant influence on the purchasing decision of $\mathrm{KFC}$ in Samarinda is to compare $t_{\text {count }}$ and $t_{\text {table. }}$. From this comparison, it is obtained that $\mathrm{t}_{\text {count }}>\mathrm{t}_{\text {table }}$ of $3.450>1.988$, it is concluded that accepting $\mathrm{H}_{a 2}$ which means the halal label has a significant influence on the purchasing decision of KFC in Samarinda.

In this case, the halal label is very important in supporting a purchase decision for consumers to buy a product, especially Muslim consumers. Muslim consumers generally have careful consideration before making a purchase regarding the halalness of food products, this is indicated by checking on a product (Prastya, 2020). The higher the influence of the halal label on a product, the more it affects consumer purchasing decisions, especially KFC in Samarinda. This is because KFC in Samarinda has a halal certificate approved by the MUI. From the statement of the halal label variable questionnaire, it can be concluded that halal labels that have guaranteed halal and cleanliness in the manufacturing process of KFC products, and include halal labels on every KFC product packaging are very important things for Muslim consumers, have also passed the halal test test. carried out by MUI and has obtained a halal halal certificate from MUI to provide certainty of halal status, so that it can 


\section{$A I C \overline{I E B}$ Annual International Conference \\ on Islamic Economics and Business, 2021}

reassure consumers and feel safer in consuming them. Understanding consumer desires for halal brands is important for companies (Ali et al., 2018).

The results of this study are in line with the research conducted by Hardiansyah and Heri Prasuhanda Manurung, but this research contradicts the research conductedDendy Khresna Bayu, Gumoyo Mumpuni Ningsih, and Livia Windiana. From the calculation of SPSS Statistics, it shows that the halal label variable has no partial effect. Evidenced by the results showing the number $0.635>0.05$. This is because consumerspay more attention to expired labels than halal labels. The condition of the majority of Indonesian people who are not familiar with halal and haram in food products tend to be ignorant (Bayu et al., 2020). People who lack knowledge or information about food products that have been labeled halal, therefore the government needs to socialize about halal labels to the public, especially Muslims (Bakhtiar et al., 2021).

\subsubsection{Effect of Product Quality (X3) on Purchase Decisions (Y)}

Based on the results of the $t$ test, $\mathrm{H}_{03}$ is rejected and $\mathrm{H}_{\mathrm{a} 3}$ is accepted. Hypothesis $\mathrm{X} \_2$ is obtained that product quality has a significant positive effect on purchasing decisions for KFC in Samarinda. Testing the effect of the halal label variable on the purchasing decision of KFC in Samarinda is known with a significant value of $0.000<0.05$ which indicates the influence of the product quality variable on the purchasing decision of KFC in Samarinda. Another way to prove that product quality has a significant influence on purchasing decisions for KFC in Samarinda is to compare $t_{\text {count }}$ and $t_{\text {table }}$. From this comparison, it is found that $\mathrm{t}_{\text {count }}>\mathrm{t}_{\text {table }}$ is $5.555>1.988$, it is concluded that accepting $\mathrm{H}_{\mathrm{a}}$ which means that product quality has a significant influence on purchasing decisions of KFC in Samarinda.

Product quality is the totality of goods or services related to consumer desires, which in terms of product excellence are worthy of being traded according to consumer expectations. Product quality is the most reliable factor by a marketer in marketing a product (Pilipus et al., 2021). In this case, product quality is the overall quality perceived by consumers for the products provided by KFC. Based on the results of the study, the influence of product quality can be caused by product features, product durability, beauty and product reliability which are considered good by consumers.

The results of this study are in line with research conducted by Hardiansyah, Heri Prasuhanda Manurung, However, this research contradicts the research conductedRizka Nur Fauziah. From the calculation of SPSS Statistics shows that the product quality variable has no significant effect on purchasing decisions seen from the value of $t_{\text {hitung }}<0.156<1.948$ and a significant value of 0.123 . If viewed from an economic point of view, the possible cause of product quality does not partially affect purchasing decisions because consumers only see the brand image of famous artists, not from the quality of the products offered. Consumers do not pay too much attention to the quality of their products but look at the brand image of the company so that consumers feel proud because they have consumed products from one of these famous artists. $t_{\text {tabel }}$ (Fauziah, 2019).

\subsubsection{Effect of Brand Image, Halal Label, Product Quality Simultaneously on Purchase Decision}

Based on the results of the $\mathrm{F}$ test (simultaneous) $\mathrm{H}_{04}$ is rejected and $\mathrm{H}_{a 4}$ is accepted. It can be seen that the significant value is $0.000<0.05$ and the value of $F_{\text {count }}$ is 44,813 so that $F_{\text {count }}>F_{\text {table }}(44.813>2.70)$. It can be concluded that $\mathrm{H}_{04}$ is rejected and $\mathrm{H}_{a 4}$ is accepted, which means that the variable brand image (X1), halal label (X2), product quality (X3) simultaneously have a significant effect on purchasing decisions (Y). This shows that 


\section{$A \mathrm{C} \overline{I E B}$ Annual International Conference \\ on Islamic Economics and Business, 2021}

KFC consumers in Samarinda pay attention to brand image, halal label, and product quality in making decisions.

\subsubsection{Dominant Variable Analysis}

Based on the results of multiple linear regression analysis, the largest regression coefficient value is found in the product quality variable of 0,392 . This means that the product quality variable has the greatest influence compared to other variables. This shows that consumers evaluate the food products offered based on the quality of taste, aroma, elasticity, and beauty of the product. A good assessment of product quality in accordance with the level of consumer wants and needs will encourage consumers to buy the product (Muliasari, 2020).

\section{Conclusion}

Based on the data collected and the tests that have been carried out on the issues raised regarding the influence of brand image, halal label, and product quality in purchasing decisions of KFC in Samarinda, the following conclusions can be drawn:

1. Brand image partially has a significant effect on purchasing decisions for KFC in Samarinda. This is because the brand image has a significant value of $0.039<0.05$ and $t_{\text {count }}>t_{\text {table }}$ of $2.092>1.988$.

2. Halal label partially has a significant effect on purchasing decisions for KFC in Samarinda. This is because the halal label has a significant value of $0.001<0.05$ and $t_{\text {count }}>t_{\text {table }}$ of $3.450>1.988$.

3. Product quality partially has a significant effect on purchasing decisions for KFC in Samarinda. This is because the product quality has a significant value of $0.000<0.05$ and $t_{\text {count }}>t_{\text {table }}$ of $5.555>1.988$.

4. Brand Image, Halal Label, Simultaneous Product Quality have a significant effect on purchasing decisions of KFC in Samarinda. This is because it has a significant value of $0.000<0.05$ and the value of $F_{\text {count }}$ is 44.813 so that $F_{\text {count }}>F_{\text {table }}(44.813>2.70)$.

5. Product quality has the largest regression coefficient value, this is indicated by a value of 0.392 , so that product quality has the greatest influence on purchasing decisions of KFC in Samarinda.

\section{Suggestion}

Based on the research results obtained, the suggestions that can be given by the author are:

1. The company is expected to continue to improve and maintain the image of the company itself and maintain the image of the products it produces, because these two components are proven to be able to become a benchmark for consumers in making decisions to buy a product.

2. Companies are expected to be able to better understand the characteristics of their customers and what they need and want. Thus the company will more easily attract consumer interest.

3. For further researchers, it is hoped that they can conduct research using different variables so that they can obtain more varied results that can affect purchasing decisions. 


\section{$A \mathrm{C} \overline{I E B}$ Annual International Conference \\ on Islamic Economics and Business, 2021}

\section{References}

Agatha, M. (2018). Analisis Pengaruh Harga Terhadap Keputusan Pembelian Batik Barong Gung Tulungagung. Jurnal Pendidikan Ekonomi, 3(2), 9.

Ali, A., Xiaoling, G., Sherwani, M., \& Ali, A. (2018). Antecedents Of Consumers' Halal Brand Purchase Intention: An Integrated Approach. Management Decision, 56(4), 715-735. Https://Doi.Org/10.1108/Md-11-2016-0785

Alić, A., Činjarević, M., \& Agić, E. (2020). The Role Of Brand Image In Consumer-Brand Relationships: Similarities And Differences Between National And Private Label Brands. Management \& Marketing. Challenges For The Knowledge Society, 15(1), 116. Https://Doi.Org/10.2478/Mmcks-2020-0001

Alshare, F., Aljawarneh, N. M., Alomari, K. A. Kader, Alomari, Z. S., Albdareen, R., Alwagfi, A. A., \& Alradaideh, A. T. (2020). Factors Influencing Cellular Device Purchase Decisions In Jordan. Management Science Letters, 2501-2506. Https://Doi.Org/10.5267/J.Msl.2020.3.045

Andari, P. (2021). Pengaruh Brand Image, Brand Trust, Dan Strategi Promosi Terhadap Keputusan Pembelian Produk Air Minum Dalam Kemasan Merek Oxgndw (Oxy). Jurnal Manajemen Dan Akuntansi, 16(1), 18.

Asti, E., \& Ayuningtyas, E. (2020). Pengaruh Kualitas Pelayanan, Kualitas Produk Dan Harga Terhadap Kepuasan Konsumen: (Effect Of Service Quality, Product Quality And Price On Consumer Satisfaction). Ekomabis: Jurnal Ekonomi Manajemen Bisnis, 1(01), 1-14. Https://Doi.Org/10.37366/Ekomabis.V1i01.2

Azam, S. M. F. (2019). Factors Influencing Customers' Purchase Decision Of Residential Property In Selangor, Malaysia. Management Science Letters, 9(9), 1341-1348. Https://Doi.Org/10.5267/J.Msl.2019.5.016

Bakhtiar, A., Ningsih, N. R., \& Sari, N. M. (2021). Impact Of Brand Image, Halal Status, And Government Certification On Purchasing Decisions For Food And Beverages. Sao Paulo, 8.

Bayu, D. K., Ningsih, G. M., \& Windiana, L. (2020). Pengaruh Labelisasi Halal, Merek Dan Harga Terhadap Keputusan Pembelian Minuman Chatime. Jurnal Sosial Ekonomi Pertanian, 16(3), 18.

Bhakuni, P., Rajput, S., Sharma, B., \& Bhakar, S. (2021). Relationship Between Brand Image And Store Image As Drivers Of Repurchase Intention In Apparel Stores. Gurukul Business Review, 17(1). Https://Doi.Org/10.48205/Gbr.V17.6

Bulan, T. P. L., Fazrin, K., \& Rizal, M. (2018). Pengaruh Label Halal Dan Bonus Dalam Kemasan Terhadap Keputusan Pembelian Pada Produk Kinder Joy Pada Masyarakat Kota Langsa. Jurnal Manajemen Dan Keuangan, 6(2), 729-739. Https://Doi.Org/10.33059/Jmk.V6i2.679

Dewanti, I. N., \& Irwansyah, I. (2021). Disonansi Kognitif Dalam Perilaku Konsumen Masyarakat Indonesia Terhadap Pembelian Produk Tanpa Logo Halal. Jurnal Lensa Mutiara Komunikasi, 5(1), 99-109. Https://Doi.Org/10.51544/Jlmk.V5i1.1657

Firmanto, Y. (2019). Pengaruh Brand Image Dan Harga Terhadap Keputusan Pembelian Konsumen Pada Produk Chicken Kfc. Jurnal Manajemen Dan Bisnis, 3(1), 10.

Fitria, A., Iriani, S. S., \& Sanaji, S. (2017). Pengaruh Brand Image Terhadap Keputusan Menggunakan Jasa Klinik Kecantikan Dengan Kelompok Referensi Sebagai Variabel Moderasi (Studi Pada Pengguna Jasa Klinik Kecantikan Di Surabaya). Jurnal Manajemen Dan Bisnis Indonesia, 4(2), 227-237. Https://Doi.Org/10.31843/Jmbi.V4i2.120

Hasan, M. I. (2003). Pokok-Pokok Statistik I (Statistic Deskriptif) Edisi Kedua, . Jakarta: Pt Bumi Aksara. 


\section{$A I C \overline{I E B}$ Annual International Conference on Islamic Economics and Business, 2021}

Hernama, \& Handrijaningsih, L. (2021). Pengaruh Labelisasi Halal, Citra Merk Dan Harga Terhadap Keputusan Pembelian Produk Mie Instan Impor Di Kalangan Mahasiswa. $U g$ Journal, 15(2), 54.

Hidayah, N., \& Rachmi, A. (2019). Pengaruh Harga Dan Lokasi Terhadap Minat Beli Konsumen Di Ayam Goreng Nelongso Malang. Jurnal Aplikasi Bisnis, 5(1), 4.

Hoe, L. C., \& Mansori, S. (2018). The Effects Of Product Quality On Customer Satisfaction And Loyalty: Evidence From Malaysian Engineering Industry. International Journal Of Industrial Marketing, 3(1), 20. Https://Doi.Org/10.5296/Ijim.V3i1.13959

Kementrian Pertanian Republik Indonesia. (2019). Suplai Ayam Melimpah, Ini Rekomendasi Dan Langkah Kementan.

Https://Www.Pertanian.Go.Id/Home/?Show=News\&Act=View\&Id=3950

Kotler, P., \& Amstrong. (2008). Prinsip-Prinsip Pemasaran. Jakarta: Erlangga.

Kotler, P., \& Keller, K. (2009). Manajemen Pemasaran. Jakarta: Erlangga.

Kountor, R. (2005). Metode Penelitian. Jakarta: Bumi Aksara.

Li, Y., Yao, J., \& Chen, J. (2021). The Negative Effect Of Scarcity Cues On Consumer Purchase Decisions In The Hospitality Industry During The Covid-19 Pandemic. International Journal Of Hospitality Management, 94, 102815. Https://Doi.Org/10.1016/J.Ijhm.2020.102815

Manurung, H. P. (2020). Pengaruh Label Halal, Kualitas Produk, Dan Harga Terhadap Keputusan Pembelian Produk. Jurnal Manajemen, Ekonomi Sains, 1(2), 9.

Marisa M, O., \& Rowena, J. (2019). Pengaruh Brand Image, Harga Dan Kualitas Produk Terhadap Keputusan Pembelian Kembali Pada Produk High End Make Up And Skin Care Pada Generasi Millenial Jakarta. Jurnal Bina Manajemen, 7(2), 165.

Mashudi. (2015). Konstruksi Hukum \& Respons Masyarakat Terhadap Sertifikasi Produk Halal. Pustaka Pelajar.

Muliasari, D. (2020). The Effect Of Product Price And Product Quality On Purchasing Decisions For Samsung Brand Handphones Among Stie Aas Surakarta Students. International Journal Of Economics, Business And Accounting Research (Ijebar), 3(04). Https://Doi.Org/10.29040/Ijebar.V3i04.805

Nguyen, C. (2021). The Determinants Of Customer Satisfaction In Fast Food Industry: The Case Study Of Kfc Viet Nam. Ssrn Electronic Journal, 2(2), 7. Https://Doi.Org/10.2139/Ssrn.3906107

Nur Fauziah, R. (2019). Pengaruh Brand Image Dan Kualitas Produk Terhadap Keputusan Pembelian I Am Geprek Bensu Tasikmalaya (Survei Pada Konsumen I Am Geprek Bensu Di Kota Tasikmalaya). Jurnal Hexagro, 3(1), 27-32. Https://Doi.Org/10.36423/Hexagro.V3i1.304

Pilipus, R. R., Aransyah, M. F., \& Bharata, W. (2021). Pengaruh Wom (Word Of Mouth), Brand Image, Dan Kualitas Produk Terhadap Keputusan Pembelian Minuman Thai Tea Pada Dum Dum Thai Drinks Samarinda. Jurnal Ilmiah Manajemen Dan Bisnis, 4(1), 12.

Sari, R. M. (2021). Pengaruh Harga Dan Kualitas Produk Terhadap Keputusan Pembelian. Jurnal Ilmiah Mea (Manajemen, Ekonomi, Dan Akuntansi), 5(3), 14.

Setyawati, K. E. (2018). Pengaruh Citra Merek (Brand Image) Terhadap Keputusan Pembelian Motor Honda Vario (Studi Kasus Pada Cv Kirana Motorindo Jaya). Jurnal Online Mahasiswa Bidang Manajemen, 3(4), 4.

Silaban, S. E., Elisabeth, E., \& Sagala, R. (2019). Pengaruh Promosi, Harga Dan Inovasi Produk Terhadap Keputusan Pembelian Pada Kentucky Fried Chicken (Kfc) Simpang Mataram Medan. Jurnal Riset Akuntansi \& Keuangan, 5(2), 209-228. Https://Doi.Org/10.54367/Jrak.V5i2.534

Soomro, Y. A., Baeshen, Y., Alfarshouty, F., Kaimkhani, S. A., \& Bhutto, M. Y. (2021). The Impact Of Guerrilla Marketing On Brand Image: Evidence From Millennial 


\section{$A I \overline{I F B}$ Annual International Conference on Islamic Economics and Business, 2021}

Consumers In Pakistan. The Journal Of Asian Finance, Economics And Business, 8(4), 917-928. Https://Doi.Org/10.13106/Jafeb.2021.Vol8.No4.0917

Susanti, I. Y., Tjahjono, E., \& Nasution, U. C. (2015). Pengaruh Brand Image, Kualitas Produk Dan Harga Terhadap Keputusan Pembelian. Jurnal Dinamika Administrasi Bisnis, 1(1), 6.

Top Brand Award. (2021). Https://Www.Topbrand-Award.Com/En/Top-Brand-IndexInt/?Tbi_Find $=\mathrm{Kfc}$

Wuhan University, China, \& Zeng, F. (2019). Chinese Smartphone Brands: Gender, Consumers Behavioural And Attitudinal Loyalty. Marketing And Management of Innovations, 2(1), 83-98. Https://Doi.Org/10.21272/Mmi.2019.2-08

Yudha Prastya, S. (2020). Pengaruh Labelisasi Halal Dan Citra Merek Terhadap Keputusan Pembelian Produk Mie Korea Pada Konsumen Di Kota Metro. Jurnal Manajemen Diversifikasi, 1(1), 9 .

Zhu, D. H., Deng, Z. Z., \& Chang, Y. P. (2020). Understanding The Influence Of Submission Devices On Online Consumer Reviews:A Comparison Between Smartphones And Pcs. Journal Of Retailing And Consumer Services, 54(2), 102028. Https://Doi.Org/10.1016/J.Jretconser.2019.102028 